Article

\title{
Co-Substitution Effect in Room-Temperature Ferromagnetic Oxide $\mathrm{Sr}_{3.1} \mathrm{Y}_{0.9} \mathrm{Co}_{4} \mathrm{O}_{10.5}$
}

\author{
Akihiro Tsuruta ${ }^{1, *} \mathbb{B}$, Shuji Kawasaki ${ }^{1,2}$, Masashi Mikami ${ }^{1}\left(\mathbb{D}\right.$, Yoshiaki Kinemuchi ${ }^{1}$, \\ Yoshitake Masuda ${ }^{1}\left(\mathbb{D}\right.$, Asaya Fujita ${ }^{1}$ and Ichiro Terasaki ${ }^{1,2} \mathbb{D}$ \\ 1 National Institute of Advanced Industrial Science and Technology (AIST), Shimo-Shidami, Moriyama-ku, \\ Nagoya 463-8560, Japan; kawasaki.shuji@e.mbox.nagoya-u.ac.jp (S.K.); m-mikami@aist.go.jp (M.M.); \\ y.kinemuchi@aist.go.jp (Y.K.); masuda-y@aist.go.jp (Y.M.); asaya-fujita@aist.go.jp (A.F.); \\ terra@nagoya-u.jp (I.T.) \\ 2 Department of Physics, Nagoya University, Furo-cho, Chuikusa-ku, Nagoya 464-8602, Japan \\ * Correspondence: a.tsuruta@aist.go.jp; Tel.: +81-52-736-7481
}

Received: 23 April 2020; Accepted: 13 May 2020; Published: 16 May 2020

check for updates

\begin{abstract}
We investigated the Co substitution effect for the magnetic properties in room-temperature ferromagnetic oxide $\mathrm{Sr}_{3.1} \mathrm{Y}_{0.9} \mathrm{Co}_{4} \mathrm{O}_{10.5}$. The substituted element ( $\mathrm{Al}$ and $\mathrm{Ga}$ ) and low-spin state $\mathrm{Co}^{3+}$, which was changed from a high-spin or intermediate-spin state by Al or Ga substitution, reduced the Curie temperature to even 1.5 times lower than the temperature estimated from a simple dilution effect. $\mathrm{Al}^{3+}$ preferentially substituted for intermediate-spin-state $\mathrm{Co}^{3+}$ in the ferrimagnetic $\mathrm{CoO}_{6}$ layer and deteriorated the saturation magnetization of $\mathrm{Sr}_{3.1} \mathrm{Y}_{0.9} \mathrm{Co}_{4} \mathrm{O}_{10.5}$. By contrast, $\mathrm{Ga}^{3+}$ substituted for high-spin-state $\mathrm{Co}^{3+}$ in the $\mathrm{CoO}_{6}$ layer and/or the antiferromagnetic $\mathrm{CoO}_{4.25}$ layer and enhanced the saturation magnetization per $\mathrm{Co}$ ion. These results indicate that the magnetic properties of $\mathrm{Sr}_{3.1} \mathrm{Y}_{0.9} \mathrm{Co}_{4} \mathrm{O}_{10.5}$ can be controlled by selectively substituting for $\mathrm{Co}^{3+}$ with different spin states.
\end{abstract}

Keywords: cobalt oxide; elemental substitution; room temperature ferromagnetism; spin state

\section{Introduction}

Among transition metal oxides with various functions, cobalt oxides are especially interesting compounds and attract attention from many researchers. Layered cobalt oxides $\left(\mathrm{Na}_{0.5} \mathrm{CoO}_{2}\right.$ and $\left.\mathrm{Ca}_{3} \mathrm{Co}_{4} \mathrm{O}_{9}\right)$ with unusual thermoelectric properties [1-4], $\mathrm{REBaCo}_{2} \mathrm{O}_{5.5}(\mathrm{RE}=$ rare earth) with giant magnetoresistance [5-7], and $\mathrm{LaCoO}_{3}$ with temperature-induced spin-state transitions [8-13] are typical compounds that have been actively studied. $\mathrm{Co}^{3+}$ ions take three types of spin state: the low-spin (LS; $S=0)$ state of $\left(t_{2 g}\right)^{6}$ and the high-spin $(H S ; S=2)$ state of $\left(e_{g}\right)^{2}\left(t_{2 g}\right)^{4}$, as well as the intermediate-spin (IS; $S=1$ ) state of $\left(\mathrm{e}_{\mathrm{g}}\right)^{1}\left(\mathrm{t}_{2 \mathrm{~g}}\right)^{5}$. The spin state of $\mathrm{Co}^{3+}$ ions is strongly related to the functions and phenomena of the cobalt oxides, and unraveling the origins of these functions has opened up new material design guidelines.

The A-site-ordered perovskite $\mathrm{Sr}_{3.1} \mathrm{Y}_{0.9} \mathrm{Co}_{4} \mathrm{O}_{10.5}$ is a weak-ferromagnetic (ferrimagnetic) material at room temperature. The transition temperature ( $T_{\mathrm{c}}$ : Curie temperature) has been reported to be around $340 \mathrm{~K}$ for polycrystalline samples [14] and $370 \mathrm{~K}$ for single-crystalline samples [15]. The crystal structure of $\mathrm{Sr}_{3.1} \mathrm{Y}_{0.9} \mathrm{Co}_{4} \mathrm{O}_{10.5}$ is shown in Figure 1a. The octahedral $\mathrm{CoO}_{6}$ layer and the oxygen-deficient (tetrahedral/pyramidal) $\mathrm{CoO}_{4.25}$ layer, which consists of tetrahedral $\mathrm{CoO}_{4}$ and pyramidal $\mathrm{CoO}_{5}$, are stacked alternately [16-19]. In this system, the two structural-phase transitions have been revealed in $\mathrm{Sr}_{3.12} \mathrm{Er}_{0.88} \mathrm{Co}_{4} \mathrm{O}_{10.5}$ [20,21]. The space group of tetragonal I4/ $\mathrm{mmm}$ in the highest-temperature phase with a $2 a \times 2 a \times 4 a$ unit cell, where $a$ is the lattice parameter of the primitive perovskite unit cell, changes into monoclinic $A 2 / m$ with a $2 \sqrt{2} a \times 2 \sqrt{2} a \times 4 a$ supercell due to oxygen vacancy ordering at $509 \mathrm{~K}$. Further, the lowest-temperature phase, in which the $a$-axis is doubled $(4 \sqrt{2} a$ 
$\times 2 \sqrt{ } 2 a \times 4 a)$, appears due to a spin state and/or orbital ordering at $360 \mathrm{~K}$. The origin of ferromagnetism in $\mathrm{Sr}_{3.1} \mathrm{Y}_{0.9} \mathrm{Co}_{4} \mathrm{O}_{10.5}$ has been revealed as the ferrimagnetism of the $\mathrm{CoO}_{6}$ layer $[14,20,22]$. In the $\mathrm{CoO}_{6}$ layer, both HS- and IS-state $\mathrm{Co}^{3+}$ exist, where the majority component is the IS state [23]. All the $\mathrm{Co}^{3+}$ ions in the $\mathrm{CoO}_{4.25}$ layer take the HS state and align antiparallel to show antiferromagnetic order [21]. Figure $1 \mathrm{~b}$ shows the magnetic structure of $\mathrm{Sr}_{3.1} \mathrm{Y}_{0.9} \mathrm{Co}_{4} \mathrm{O}_{10.5}$. The saturation magnetization simply expected from this structure is $0.25 \mu_{\mathrm{B}} / \mathrm{Co}$. In this material, a spin-state crossover, which is a change from the HS- and IS-states in the $\mathrm{CoO}_{6}$ layer into the LS state, is observed around $150 \mathrm{~K}$. Additionally, it has been reported that the spin-state crossover is enhanced by physical pressure [24] and chemical pressure owing to the pressure-induced enlargement of the crystal-field splitting [25]. In this interesting cobalt oxide, so far, various kinds of investigations [26-30] have been conducted and the A-site substitution has been actively studied in order to reveal and control the spin state of Co ions [25,31,32].

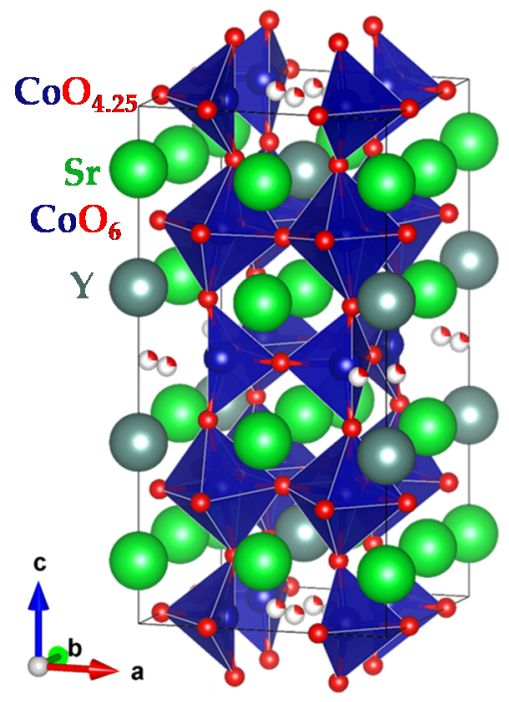

(a)

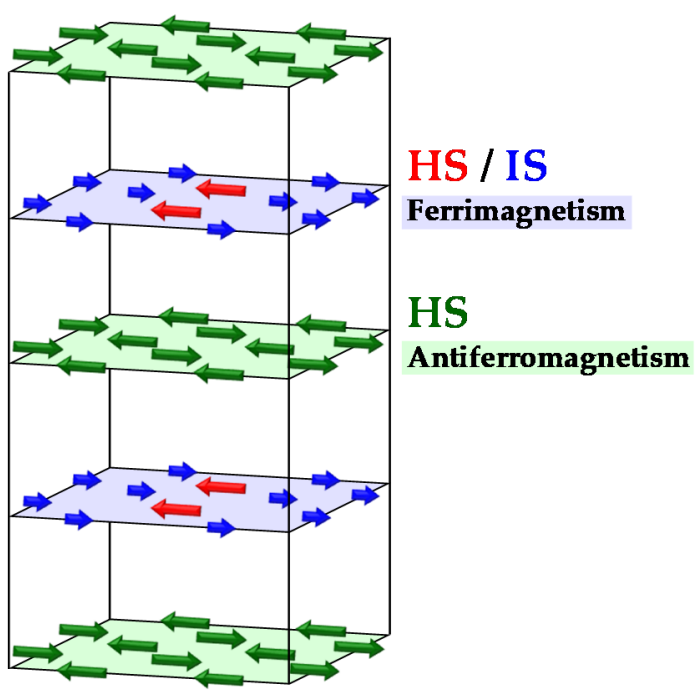

(b)

Figure 1. (a) Crystal structure and (b) magnetic structure of $\mathrm{Sr}_{3.1} \mathrm{Y}_{0.9} \mathrm{Co}_{4} \mathrm{O}_{10.5}$.

In this study, we substituted nonmagnetic elements of $\mathrm{Al}$ and $\mathrm{Ga}$ with different ionic radii for the B-site (Co-site) and measured the magnetic properties of $\operatorname{Sr}_{3.1} \mathrm{Y}_{0.9} \mathrm{Co}_{4-x} B_{x} \mathrm{O}_{10.5}(B=\mathrm{Al}$ and Ga: $x=0$, 0.2 , and 0.4 ). It was expected that the Curie temperature would be reduced towards room temperature by a simple dilution effect. Moreover, the ferrimagnetism of the $\mathrm{CoO}_{6}$ layer, which is responsible for the magnetization of $\mathrm{Sr}_{3.1} \mathrm{Y}_{0.9} \mathrm{Co}_{4} \mathrm{O}_{10.5}$, was expected to be controlled through selective substitution.

\section{Experimental}

$\mathrm{Sr}_{3.1} \mathrm{Y}_{0.9} \mathrm{Co}_{4-x} B_{x} \mathrm{O}_{10.5}(B=\mathrm{Al}$ and $\mathrm{Ga}: x=0,0.2$, and 0.4$)$ polycrystalline samples were prepared by a solid-state reaction. $\mathrm{SrCO}_{3}, \mathrm{Y}_{2} \mathrm{O}_{3}, \mathrm{Co}_{3} \mathrm{O}_{4}, \mathrm{Al}_{2} \mathrm{O}_{3}$, and $\mathrm{Ga}_{2} \mathrm{O}_{3}$ were mixed and calcined at $1100{ }^{\circ} \mathrm{C}$ for $12 \mathrm{~h}$ in air. The calcined products were ground, pressed into pellets, and sintered at $1100{ }^{\circ} \mathrm{C}$ for $48 \mathrm{~h}$ in air. To compensate Co evaporation during calcining and sintering, 5-mol $\% \mathrm{Co}_{3} \mathrm{O}_{4}$ was added from the stoichiometric ratio, following the previous report [25].

X-ray diffraction (XRD) patterns of the ground samples were taken with $\mathrm{CuK} \alpha(\lambda=1.5418 \AA)$ radiation using a standard diffractometer with monochromator (Rigaku, SmartLab, Tokyo, Japan). The $2 \theta-\theta$ scan was carried out with a continuous-scan mode from 20 to $80^{\circ}$ at $5^{\circ} / \mathrm{min}$. The magnetization was measured from 2 to $350 \mathrm{~K}$ by a commercial superconducting quantum interference device magnetometer (Quantum Design, MPMS, San Diego, CA, USA). We applied $\mu_{0} H=0.1 \mathrm{~T}$ for the measurement of magnetization-temperature $(M-T)$ data and measured the magnetization $M$ in sweeping field $\mu_{0} H$ from -7 to $7 \mathrm{~T}$ at $2 \mathrm{~K}$. 


\section{Results and Discussion}

Figure 2a shows the XRD patterns of $\mathrm{Sr}_{3.1} \mathrm{Y}_{0.9} \mathrm{Co}_{4-x} B_{x} \mathrm{O}_{10.5}$ powders. All the peaks of the samples are indexed as $\mathrm{Sr}_{3.1} \mathrm{Y}_{0.9} \mathrm{Co}_{4} \mathrm{O}_{10.5}$ phase without any impurity phases. The $2 \theta$ values systematically shift according to the substituted element and amount. The axis lengths and the lattice volumes calculated from the XRD patterns are shown in Figure 2b. Both $a$ - and $c$-axis lengths of $\operatorname{Sr}_{3.1} \mathrm{Y}_{0.9} \mathrm{Co}_{4-x} \mathrm{Al}_{x} \mathrm{O}_{10.5}$ are found to decrease with increasing $\mathrm{Al}$ content within experimental uncertainties. On the other hand, in $\mathrm{Sr}_{3.1} \mathrm{Y}_{0.9} \mathrm{Co}_{4-x} \mathrm{Ga}_{x} \mathrm{O}_{10.5}$, the two lengths increase with increasing Ga content. Consequently, the lattice volumes of $\mathrm{Sr}_{3.1} \mathrm{Y}_{0.9} \mathrm{Co}_{4-x} \mathrm{Al}_{x} \mathrm{O}_{10.5}$ and $\mathrm{Sr}_{3.1} \mathrm{Y}_{0.9} \mathrm{Co}_{4-x} \mathrm{Ga}_{x} \mathrm{O}_{10.5}$ decrease and increase with increasing $B$ content, respectively. The ionic radii of $\mathrm{Co}^{3+}, \mathrm{Al}^{3+}$, and $\mathrm{Ga}^{3+}$ are listed in Table 1. In the case of $\mathrm{Co}^{3+}$, the radii depend on the spin state. $\mathrm{Co}^{3+}$ ions in any spin state are larger than $\mathrm{Al}^{3+}$ ions and smaller than $\mathrm{Ga}^{3+}$ ions. The changes in lattice volume due to Co substitution are well explained in terms of the ionic radii, but the substitution sites for both $\mathrm{Al}^{3+}$ and $\mathrm{Ga}^{3+}$ could not be determined from the axis length and the lattice volume.

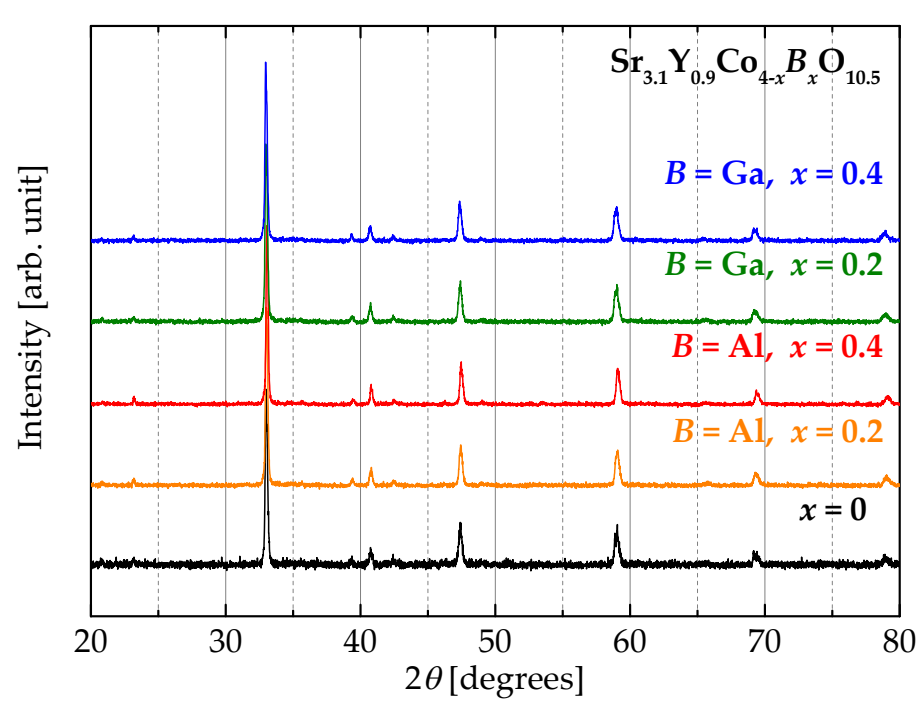

(a)

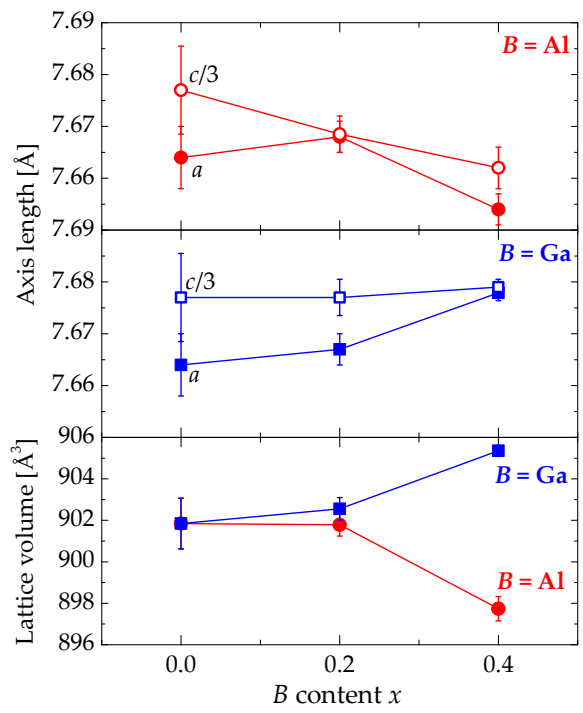

(b)

Figure 2. (a) $\mathrm{XRD}(\mathrm{CuK} \alpha)$ patterns of $\mathrm{Sr}_{3.1} \mathrm{Y}_{0.9} \mathrm{Co}_{4-x} B_{x} \mathrm{O}_{10.5}(B=\mathrm{Al}$ and $\mathrm{Ga}: x=0,0.2$, and 0.4$)$ powders. (b) The axis lengths and the lattice volumes of $\mathrm{Sr}_{3.1} \mathrm{Y}_{0.9} \mathrm{Co}_{4-x} B_{x} \mathrm{O}_{10.5}$ as a function of $B$ content.

Table 1. Ionic radii of high-spin (HS), intermediate-spin (IS), and low-spin (LS) states $\mathrm{Co}^{3+}, \mathrm{Al}^{3+}$, and $\mathrm{Ga}^{3+}$.

\begin{tabular}{|c|c|c|c|c|c|}
\hline Ion & $\mathrm{Co}^{3+}$ (HS) [33] & $\mathrm{Co}^{3+}(\mathrm{IS})$ & $\mathrm{Co}^{3+}(\mathrm{LS})$ & $\mathrm{Al}^{3+} \quad[33]$ & $\mathrm{Ga}^{3+} \quad$ [33] \\
\hline Radius [Å] & 0.61 & 0.56 & 0.545 & 0.535 & 0.62 \\
\hline
\end{tabular}

Figure 3 a shows the field-cooled $M-T$ curves of $\mathrm{Sr}_{3.1} \mathrm{Y}_{0.9} \mathrm{Co}_{4-x} B_{x} \mathrm{O}_{10.5}$. In both cases of $B=\mathrm{Al}$ and $\mathrm{Ga}$, the magnetic transition shifts to low temperatures with increasing substitution amounts of $B$. The Curie temperature $\left(T_{\mathrm{c}}\right)$ is unable to be determined using the Curie-Weiss law because the magnetic transition of this system is of first order. Then, we estimate the $T_{\mathrm{c}}$ from inflection points in the temperature derivative of the $M-T$ curves.

The normalized $T_{\mathrm{c}}\left(T_{\mathrm{c}}(x) / T_{\mathrm{c}}(0)\right)$ of $\mathrm{Sr}_{3.1} \mathrm{Y}_{0.9} \mathrm{Co}_{4-x} B_{x} \mathrm{O}_{10.5}$ by $T_{\mathrm{c}}$ of $\mathrm{Sr}_{3.1} \mathrm{Y}_{0.9} \mathrm{Co}_{4} \mathrm{O}_{10.5}$ is shown in Figure $3 \mathrm{~b}$ as a function of substitution ratio of $\operatorname{Co}$ by $B(x / 4)$. The expected $T_{\mathrm{c}}$ reduction from a simple dilution effect due to Co substitution is shown by the dashed line. The $T_{c}$ 's of $\operatorname{Sr}_{3.1} \mathrm{Y}_{0.9} \mathrm{Co}_{4-x} \mathrm{Al}_{x} \mathrm{O}_{10.5}$ and $\mathrm{Sr}_{3.1} \mathrm{Y}_{0.9} \mathrm{Co}_{4-x} \mathrm{Ga}_{x} \mathrm{O}_{10.5}$ coincide with each other and are 1.5 times lower than the $T_{\mathrm{c}}$ expected from the dilution effect. Assuming that the dilution effects is valid, we expect that the $\mathrm{Al}$ and $\mathrm{Ga}$ substitutions should generate additional nonmagnetic Co ions. In other words, Al or Ga substitution for the Co site 
may drive neighboring $\mathrm{Co}^{3+}$ from the HS or IS state into the nonmagnetic LS state. The magnetization reduction due to the spin-state crossover, which is indicated by the thick arrow in Figure 3a, is observed around $150 \mathrm{~K}$ only in $\mathrm{Sr}_{3.1} \mathrm{Y}_{0.9} \mathrm{Co}_{4} \mathrm{O}_{10.5}$. Hence, both $\mathrm{Al}$ and $\mathrm{Ga}$ substitutions suppress the spin-state crossover. The transition from the HS or IS state to the LS state at low temperature is no longer necessary because some $\mathrm{Co}^{3+}$ has already been stabilized to the LS state by $\mathrm{Al} / \mathrm{Ga}$ substitution.

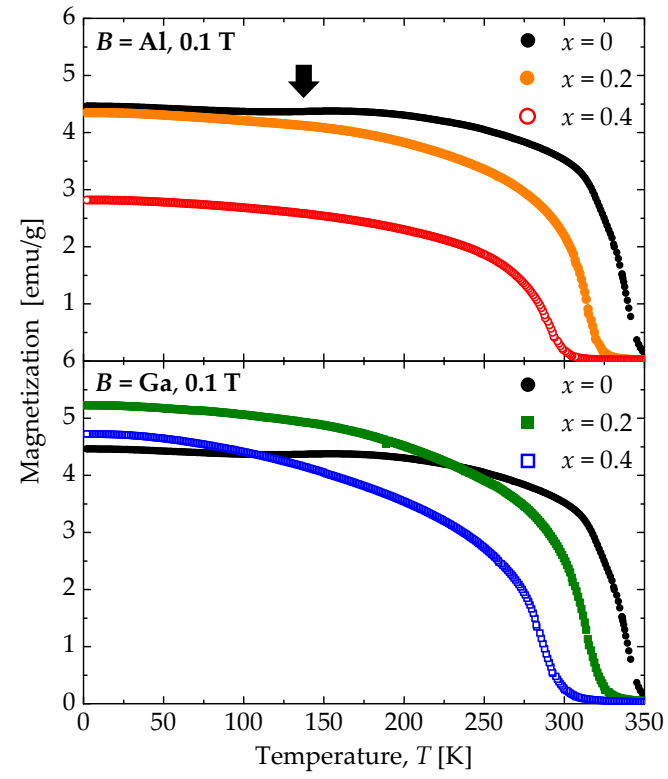

(a)

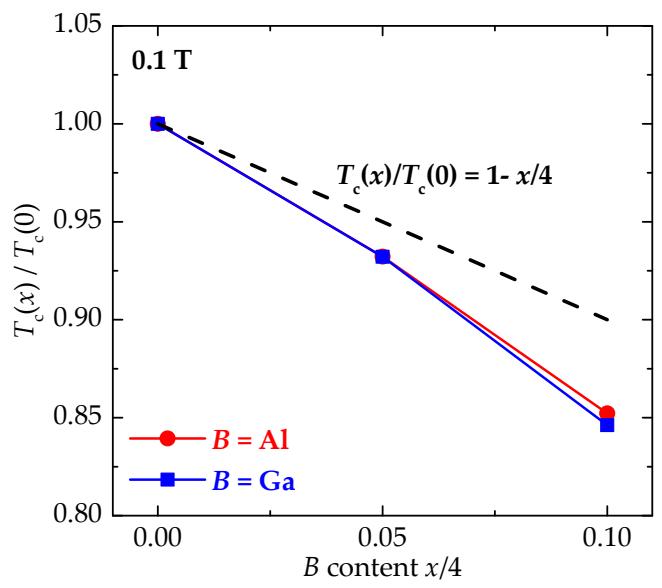

(b)

Figure 3. (a) Temperature dependence of the magnetization of $\mathrm{Sr}_{3.1} \mathrm{Y}_{0.9} \mathrm{Co}_{4-x} B_{x} \mathrm{O}_{10.5}(B=\mathrm{Al}$ and Ga: $x=0,0.2$, and 0.4$)$ under $0.1 \mathrm{~T}$. (b) The normalized Curie temperature $\left(T_{\mathrm{c}}(x) / T_{\mathrm{c}}(0)\right)$ of $\mathrm{Sr}_{3.1} \mathrm{Y}_{0.9} \mathrm{Co}_{4-x} B_{x} \mathrm{O}_{10.5}$ by $T_{\mathrm{c}}$ of $\mathrm{Sr}_{3.1} \mathrm{Y}_{0.9} \mathrm{Co}_{4} \mathrm{O}_{10.5}$ as a function of substitution ratio of $\mathrm{Co}$ by $B(x / 4) . T_{\mathrm{c}}$ has been estimated from the inflection points in the temperature derivative of the $M-T$ curve.

The magnetic field dependence of magnetization of $\mathrm{Sr}_{3.1} \mathrm{Y}_{0.9} \mathrm{Co}_{4-x} B_{x} \mathrm{O}_{10.5}$ at $2 \mathrm{~K}$ is shown in Figure 4a. The high-field magnetization depends on the substitution element and amount. Since the $\mathrm{Sr}_{3.1} \mathrm{Y}_{0.9} \mathrm{Co}_{4-x} B_{x} \mathrm{O}_{10.5}$ system shows ferrimagnetic order, the magnetization does not saturate but continues to increase with the increasing magnetic field. Then, we define the saturation magnetization $\left(M_{\mathrm{s}}\right)$ as the $y$ intercept of the linearly extrapolated line from the high-field $M-H$ curve, as shown by the dashed line in Figure 4a.

The $M_{\mathrm{s}}$ of $\mathrm{Sr}_{3.1} \mathrm{Y}_{0.9} \mathrm{Co}_{4-x} B_{x} \mathrm{O}_{10.5}$ at $2 \mathrm{~K}$ is shown in Figure $4 \mathrm{~b}$ as a function of the $B$ content $x$. The $M_{\mathrm{s}}$ of $\mathrm{Sr}_{3.1} \mathrm{Y}_{0.9} \mathrm{Co}_{4} \mathrm{O}_{10.5}$ is smaller than the $M_{\mathrm{S}}=0.25 \mu_{\mathrm{B}} /$ Co expected from the magnetic structure because some magnetic $\mathrm{Co}^{3+}$ has experienced the spin-state crossover to the nonmagnetic LS state at $2 \mathrm{~K}$. Since $M_{\mathrm{S}}$ is referred to as the magnetization per Co ion (not per unit cell), $M_{\mathrm{S}}$ is expected to remain intact if $\mathrm{Al}$ or $\mathrm{Ga}$ is substituted for Co randomly. If we ascribe the 1.5-times faster reduction of $T_{\mathrm{C}}$ to nonmagnetic Co ions additionally induced by $\mathrm{Al} / \mathrm{Ga}$ substitution, $\mathrm{Al} / \mathrm{Ga}$ substitution drives some portions of the neighboring Co ions to the LS state. We can estimate an amount of LS-state Co ions induced by $\mathrm{Al} / \mathrm{Ga}$ substitution by assuming that the dilution effect is valid. Taking the estimated amount of LS-state Co ions with $\mathrm{Al} / \mathrm{Ga}$ random substitution into account, we evaluate $M_{\mathrm{S}}$ to be 0.243 and $0.236 \mu_{\mathrm{B}} / \mathrm{Co}$ at $x=$ 0.2 and 0.4, respectively, as shown by the open circles. The $M_{\mathrm{S}}$ of $\mathrm{Sr}_{3.1} \mathrm{Y}_{0.9} \mathrm{Co}_{4-x} \mathrm{Ga}_{x} \mathrm{O}_{10.5}$ is larger than the calculated values and clearly increases with increasing Ga content. On the other hand, the $M_{\mathrm{S}}$ of $\mathrm{Sr}_{3.1} \mathrm{Y}_{0.9} \mathrm{Co}_{4-x} \mathrm{Al}_{x} \mathrm{O}_{10.5}$ is smaller than the calculated values and decreases with increasing $\mathrm{Al}$ content. These obvious differences between $\mathrm{Al}$ and $\mathrm{Ga}$ substitutions suggest different substitution sites. 


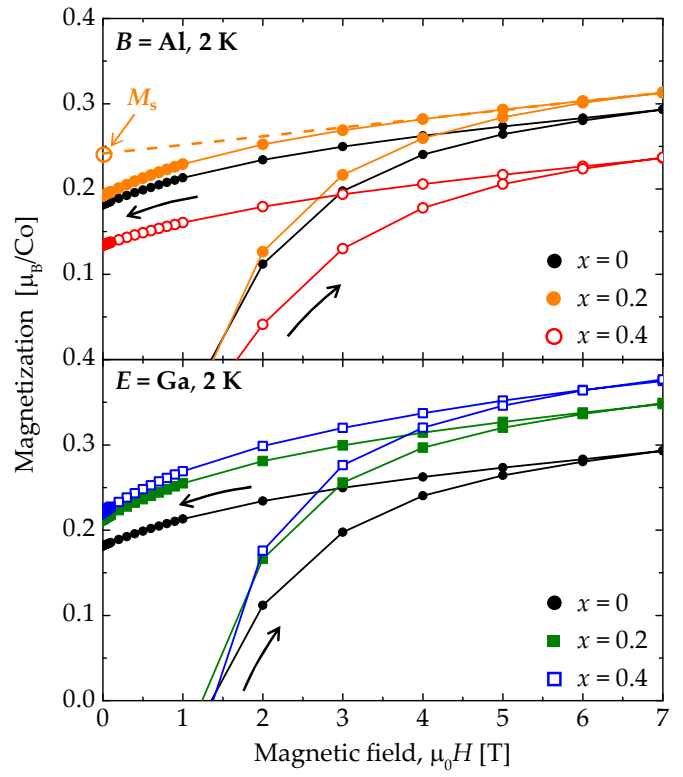

(a)

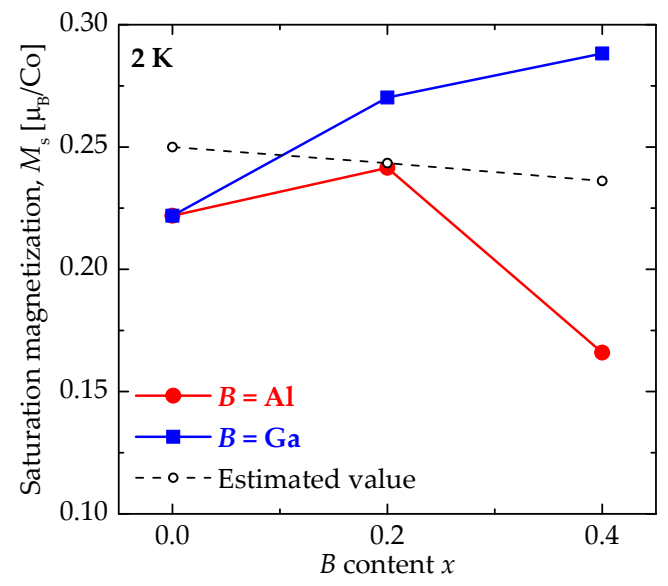

(b)

Figure 4. (a) Magnetic field dependence of the magnetization of $\operatorname{Sr}_{3.1} \mathrm{Y}_{0.9} \mathrm{Co}_{4-x} B_{x} \mathrm{O}_{10.5}(B=\mathrm{Al}$ and $\mathrm{Ga}$ : $x=0,0.2$, and 0.4 ) at $2 \mathrm{~K}$. (b) Saturation magnetization $M_{\mathrm{S}}$ of $\mathrm{Sr}_{3.1} \mathrm{Y}_{0.9} \mathrm{Co}_{4-x} B_{x} \mathrm{O}_{10.5}$ as a function of the E content $x$.

When the HS-state $\mathrm{Co}^{3+}$ in the $\mathrm{CoO}_{4.25}$ layer is substituted, the magnetization per unit cell will retain the same value because the $\mathrm{CoO}_{4.25}$ layer is antiferromagnetic. Note that, since $M_{\mathrm{s}}$ is referred to as the magnetization per $C o$ ion, the magnetization per unit cell independent of $B$ content implies that $M_{\mathrm{s}}$ increases with decreasing amounts of $\mathrm{Co}$ ion in the unit cell due to the substitution. If the HS-state $\mathrm{Co}^{3+}$ in the $\mathrm{CoO}_{6}$ layer is substituted, magnetization should increase with the substitution amount because it is the minority in the ferrimagnetic $\mathrm{CoO}_{6}$ layer. On the other hand, the substitution for the IS-state $\mathrm{Co}^{3+}$ in the ferrimagnetic $\mathrm{CoO}_{6}$ layer should decrease the magnetization. Hence, we suggest that $\mathrm{Al}^{3+}$ and $\mathrm{Ga}^{3+}$ are expected to substitute for the IS-state $\mathrm{Co}^{3+}$ in the $\mathrm{CoO}_{6}$ layer and HS-state $\mathrm{Co}^{3+}$ in the $\mathrm{CoO}_{6}$ or $\mathrm{CoO}_{4.25}$ layers, respectively. This suggestion is supported by the size of the ionic radius listed in Table 1. $\mathrm{Al}^{3+}$ is close to IS-state $\mathrm{Co}^{3+}$ in size, while $\mathrm{Ga}^{3+}$ is close to HS-state $\mathrm{Co}^{3+}$ in size.

Finally, we estimate $M_{\mathrm{S}}$ of $\mathrm{Sr}_{3.1} \mathrm{Y}_{0.9} \mathrm{Co}_{4-x} B_{x} \mathrm{O}_{10.5}$ along with our suggestion. It is assumed that the LS-state $\mathrm{Co}$ ions induced by $\mathrm{Al} / \mathrm{Ga}$ substitution distribute randomly. If Ga substitutes for the HS-state $\mathrm{Co}^{3+}$ in the $\mathrm{CoO}_{6}$ or $\mathrm{CoO}_{4.25}$ layers randomly, $M_{\mathrm{s}}$ 's are estimated to be 0.271 and $0.292 \mu_{\mathrm{B}} / \mathrm{Co}$ at $x=0.2$ and 0.4 , respectively. Both values are in good agreement with the measured values shown in Figure $4 \mathrm{~b}$. On the other hand, if $\mathrm{Al}$ substitutes for the IS-state $\mathrm{Co}^{3+}$ in the $\mathrm{CoO}_{6}$ layer, $M_{\mathrm{s}}$ 's are estimated to be 0.205 and $0.157 \mu_{\mathrm{B}} / \mathrm{Co}$ at $x=0.2$ and 0.4 , respectively. The values are somewhat smaller than the measured values. Therefore, $\mathrm{Al}$ mainly substitutes for the IS-state $\mathrm{Co}^{3+}$, but a part of $\mathrm{Al}$ would also substitute HS-state $\mathrm{Co}^{3+}$.

\section{Conclusions}

We measured and analyzed the magnetic properties of Co-substituted $\operatorname{Sr}_{3.1} \mathrm{Y}_{0.9} \mathrm{Co}_{4-x} B_{x} \mathrm{O}_{10.5}(B=\mathrm{Al}$ and Ga: $x=0,0.2$, and 0.4). We found that the Curie temperatures of both $\operatorname{Sr}_{3.1} \mathrm{Y}_{0.9} \mathrm{Co}_{4-x} \mathrm{Al}_{x} \mathrm{O}_{10.5}$ and $\mathrm{Sr}_{3.1} \mathrm{Y}_{0.9} \mathrm{Co}_{4-x} \mathrm{Ga}_{x} \mathrm{O}_{10.5}$ are about 1.5 times lower than the temperature estimated from the simple dilution effect. This extra Curie-temperature reduction is understood in terms of the LS-state $\mathrm{Co}^{3+}$ additionally induced by the Co site substitution. A mechanism of the LS-state $\mathrm{Co}^{3+}$ inducement by the substitution is not made clear in this study but should be revealed in future work. The saturation magnetization of $\mathrm{Sr}_{3.1} \mathrm{Y}_{0.9} \mathrm{Co}_{4-x} \mathrm{Al}_{x} \mathrm{O}_{10.5}$ decreases with $\mathrm{Al}$ content, whereas that of $\mathrm{Sr}_{3.1} \mathrm{Y}_{0.9} \mathrm{Co}_{4-x} \mathrm{Ga}_{x} \mathrm{O}_{10.5}$ increases with $\mathrm{Ga}$ content. This different behavior suggests the selectivity 
of the substitution site depends on the substituted element. $\mathrm{Al}^{3+}$ close to the IS-state $\mathrm{Co}^{3+}$ in ionic size suppresses the magnetization through substituting the majority component of the IS-state $\mathrm{Co}^{3+}$ in the ferrimagnetic $\mathrm{CoO}_{6}$ layer. By contrast, the substitution for the minority component of the HS-state $\mathrm{Co}^{3+}$ in $\mathrm{CoO}_{6}$ layer and/or HS-state $\mathrm{Co}^{3+}$ in antiferromagnetic $\mathrm{CoO}_{4.25}$ layer by $\mathrm{Ga}^{3+}$ enhances the magnetization. The present study suggests that the magnetization of the room-temperature ferromagnetic oxide $\mathrm{Sr}_{3.1} \mathrm{Y}_{0.9} \mathrm{Co}_{4} \mathrm{O}_{10.5}$ can be controlled by the selective substitution for Co site according to the ionic radius of the substituting elements.

Author Contributions: S.K., A.T., and I.T. conceived and designed the experiments; S.K. and A.T. performed the experiments; S.K. and I.T. analyzed the data; M.M., Y.K., Y.M., and A.F. helped with the experiments and discussed the results; A.T. wrote the paper. All authors have read and agreed to the published version of the manuscript.

Funding: This research received no external funding.

Conflicts of Interest: The authors declare no conflict of interest.

\section{References}

1. Terasaki, I.; Sasago, Y.; Uchinokura, K. Large thermoelectric power in $\mathrm{NaCo}_{2} \mathrm{O}_{4}$ single crystals. Phys. Rev. $B$ 1997, 56, R12685. [CrossRef]

2. Koshibae, W.; Tsutsui, K.; Maekawa, S. Thermopower in cobalt oxides. Phys. Rev. B 2000, 62, 6869-6872. [CrossRef]

3. Funahashi, R.; Matsubara, I.; Ikuma, H.; Takeuchi, T.; Mizutani, U.; Sodeoka, S. An Oxide Single Crystal with High Thermoelectric Performance in Air. Jpn. J. Appl. Phys. 2000, 39, L1127-L1129. [CrossRef]

4. Shikano, M.; Funahashi, R. Electrical and thermal properties of single-crystalline $\left(\mathrm{Ca}_{2} \mathrm{CoO}_{3}\right)_{0.7} \mathrm{CoO}_{2}$ with a $\mathrm{Ca}_{3} \mathrm{Co}_{4} \mathrm{O}_{9}$ structure. Appl. Phys. Lett. 2003, 82, 1851. [CrossRef]

5. Pérez, J.; García, J.; Blasco, J.; Stankiewicz, J. Spin-Glass Behavior and Giant Magnetoresistance in the (RE) $\mathrm{Ni}_{0.3} \mathrm{Co}_{0.7} \mathrm{O}_{3}$ (RE=La,Nd,Sm) System. Phys. Rev. Lett. 1998, 80, 2401. [CrossRef]

6. Troyanchuk, I.O.; Kasper, N.V.; Khalyavin, D.D.; Szymczak, H.; Szymczak, R.; Baran, M. Phase Transitions in the $\mathrm{Gd}_{0.5} \mathrm{Ba}_{0.5} \mathrm{CoO}_{3}$ Perovskite. Phys. Rev. Lett. 1998, 80, 3380. [CrossRef]

7. Taskin, A.A.; Lavrov, A.N.; Yoichi, A. Ising-Like Spin Anisotropy and Competing Antiferromagnetic-Ferromagnetic Orders in $\mathrm{GdBaCo}_{2} \mathrm{O}_{5.5}$ Single Crystals. Phys. Rev. Lett. 2003, 90, 227201. [CrossRef]

8. Raccah, P.M.; Goodenough, J.B. First-Order Localized-Electron Collective-Electron Transition in $\mathrm{LaCoO}_{3}$. Phy. Rev. 1967, 155, 932. [CrossRef]

9. Asai, K.; Yokokura, O.; Nishimori, N.; Chou, H.; Tranquada, J.M.; Shirane, G.; Higuchi, S.; Okajima, Y.; Kohn, K. Neutron-scattering study of the spin-state transition and magnetic correlations in $\mathrm{La}_{1-\mathrm{x}} \mathrm{Sr}_{\mathrm{x}} \mathrm{CoO}_{3}$ (x= 0 and 0.08). Phys. Rev. B 1994, 50, 3025. [CrossRef]

10. Korotin, M.A.; Ezhov, S.Y.; Solovyev, I.V.; Anisimov, V.I.; Khomskii, D.I.; Sawatzky, G.A. Intermediate-spin state and properties of $\mathrm{LaCoO}_{3}$. Phys. Rev. B 1996, 54, 5309. [CrossRef]

11. Asai, K.; Yoneda, A.; Yokokura, O.; Tranquada, J.M.; Shirane, G.; Kohn, K. Two Spin-State Transitions in $\mathrm{LaCoO}_{3}$. J. Phys. Soc. Jpn. 1998, 67, 290-296. [CrossRef]

12. Knížek, K.; Novák, P.; Jirák, Z. Spin state of $\mathrm{LaCoO}_{3}$ : Dependence on $\mathrm{CoO}_{6}$ octahedra geometry. Phys. Rev. B 2005, 71, 054420. [CrossRef]

13. Tomiyasu, K.; Okamoto, J.; Huang, H.Y.; Chen, Z.Y.; Sinaga, E.P.; Wu, W.B.; Chu, Y.Y.; Singh, A.; Wang, R.-P.; de Groot, F.M.F.; et al. Coulomb Correlations Intertwined with Spin and Orbital Excitations in $\mathrm{LaCoO}_{3}$. Phys. Rev. Lett. 2017, 119, 196402. [CrossRef] [PubMed]

14. Kobayashi, W.; Ishiwata, S.; Terasaki, I.; Takano, M.; Grigoraviciute, I.; Yamauchi, H.; Karppinen, M. Room-temperature ferromagnetism in $\mathrm{Sr}_{1-\mathrm{x}} \mathrm{Y}_{\mathrm{x}} \mathrm{CoO}_{3-\delta}(0.2 \leq \mathrm{x} \leq 0.25)$. Phys. Rev. B 2005, 72, 104408. [CrossRef]

15. Kobayashi, W.; Terasaki, I. Room Temperature Ferromagnetism in a $\operatorname{Sr}_{0.75} \mathrm{Y}_{0.25} \mathrm{CoO}_{2.64}$ Single Crystal. AIP Conf. Proc. 2006, 850, 1223. [CrossRef]

16. Withers, R.L.; James, M.; Goossens, D.J. Atomic ordering in the doped rare earth cobaltates $L n_{0.33} \mathrm{Sr}_{0.67} \mathrm{CoO}_{3-\delta}$ $\left(\mathrm{Ln}=\mathrm{Y}^{3+}, \mathrm{Ho}^{3+}\right.$ and $\left.\mathrm{Dy}^{3+}\right)$. J. Solid State Chem. 2003, 174, 198-208. [CrossRef] 
17. Istomin, S.Y.; Grins, J.; Svensson, G.; Drozhzhin, O.A.; Kozhevnikov, V.L.; Antipov, E.V.; Attfield, J.P. Crystal Structure of the Novel Complex Cobalt Oxide $\mathrm{Sr}_{0.7} \mathrm{Y}_{0.3} \mathrm{CoO}_{2.62}$. Chem. Mater. 2003, 15, 4012-4020. [CrossRef]

18. Istomin, S.Y.; Drozhzhin, O.A.; Svensson, G.; Antipov, E.V. Synthesis and characterization of $\operatorname{Sr}_{1-x} \operatorname{Ln}_{x} \mathrm{CoO}_{3-\delta}$, Ln $=\mathrm{Y}, \mathrm{Sm}-\mathrm{Tm}, 0.1 \leq x \leq 0.5$. Solid State Sci. 2004, 6, 539-546. [CrossRef]

19. Sheptyakov, D.V.; Pomjakushin, V.Y.; Drozhzhin, O.A.; Istomin, S.Y.; Antipov, E.V.; Bobrikov, I.A.; Balagurov, A.M. Correlation of chemical coordination and magnetic ordering in $\mathrm{Sr}_{3} \mathrm{YCo}_{4} \mathrm{O}_{10.5+\delta}(\delta=$ 0.02 and 0.26). Phys. Rev. B 2009, 80, 024409. [CrossRef]

20. Ishiwata, S.; Kobayashi, W.; Terasaki, I.; Kato, K.; Takata, M. Structure-property relationship in the ordered-perovskite-related oxide $\mathrm{Sr}_{3.12} \mathrm{Er}_{0.88} \mathrm{Co}_{4} \mathrm{O}_{10.5}$. Phys. Rev. B 2007, 75, 220406(R). [CrossRef]

21. Nakao, H.; Murata, T.; Bizen, D.; Murakami, Y.; Ohoyama, K.; Yamada, K.; Ishiwata, S.; Kobayashi, W.; Terasaki, I. Orbital Ordering of Intermediate-Spin State of $\mathrm{Co}^{3+}$ in $\mathrm{Sr}_{3} \mathrm{YCo}_{4} \mathrm{O}_{10.5}$. J. Phys. Soc. Jpn. 2011, 80, 023711. [CrossRef]

22. Nakao, A.; Nakao, H.; Ohoyama, K.; Torii, S.; Zhang, J.; Kamiyama, T.; Murakami, Y.; Kobayashi, W.; Terasaki, I. Magnetic and Crystal Structures of the Room Temperature Ferrimagnet $\mathrm{Sr}_{3} \mathrm{YCo}_{4} \mathrm{O}_{10.5}$. JPS Conf. Proc. 2015, 8, 034010. [CrossRef]

23. Golosova, N.O.; Kozlenko, D.P.; Dubrovinsky, L.S.; Drozhzhin, O.A.; Istomin, S.Y.; Savenko, B.N. Spin state and magnetic transformations in $\mathrm{Sr}_{0.7} \mathrm{Y}_{0.3} \mathrm{CoO}_{2.62}$ at high pressures. Phys. Rev. B 2009, 79, 104431. [CrossRef]

24. Takahashi, H.; Ishiwata, S.; Okazaki, R.; Yasui, Y.; Terasaki, I. Enhanced thermopower via spin-state modification. Phys. Rev. B 2018, 98, 024405. [CrossRef]

25. Yoshida, S.; Kobayashi, W.; Nakano, T.; Terasaki, I.; Matsubayashi, K.; Uwatoko, Y.; Grigoraviciute, I.; Karppinen, M.; Yamauchi, H. Chemical and Physical Pressure Effects on the Magnetic and Transport Properties of the A-Site Ordered Perovskite $\mathrm{Sr}_{3} \mathrm{YCo}_{4} \mathrm{O}_{10.5}$. J. Phys. Soc. Jpn. 2009, 78, 094711. [CrossRef]

26. Khalyavin, D.D.; Chapon, L.C.; Suard, E.; Parker, J.E.; Thompson, S.P.; Yaremchenko, A.A.; Kharton, V.V. Complex room-temperature ferrimagnetism induced by zigzag stripes of oxygen vacancies in $\mathrm{Sr}_{3} \mathrm{YCo}_{4} \mathrm{O}_{10+\delta}$. Phys. Rev. B 2011, 83, 140403(R). [CrossRef]

27. Troyanchuk, I.O.; Bushinsky, M.V.; Dobryanskii, V.M.; Pushkarev, N.V. First-order magnetic phase transition in layered $\mathrm{Sr}_{3} \mathrm{YCo}_{4} \mathrm{O}_{10.5+\delta}$-type cobaltites. JETP Lett. 2012, 94, 849-852. [CrossRef]

28. Rupasov, D.; Makarenko, T.; Jacobson, A.J. Oxygen diffusion in $\mathrm{Sr}_{3} \mathrm{YCo}_{4} \mathrm{O}_{10.5}$ : An electrical conductivity relaxation and thermogravimetric analysis approach. Solid State Ionics 2014, 265, 68-72. [CrossRef]

29. Marik, S.; Mohanty, P.; Singh, D.; Singh, R.P. Moderate magnetic field induced large exchange bias effect in ferrimagnetic 314- $\mathrm{Sr}_{3} \mathrm{YCo}_{4} \mathrm{O}_{10.5}$ material. J. Phys. D Appl. Phys. 2018, 51, 065006. [CrossRef]

30. Troyanchuk, I.O.; Bushinsky, M.V.; Tereshko, N.V.; Lanovsky, R.A.; Sikolenko, V.V.; Ritter, C.; Orlov, Y.S.; Ovchinnikov, S.G. Ferromagnet-antiferromagnet transition in layered perovskites of $\mathrm{Sr}_{3} \mathrm{YCo}_{4} \mathrm{O}_{10.5}$ type. Mater. Res. Express 2019, 6, 026105. [CrossRef]

31. James, M.; Cassidy, D.; Goossens, D.J.; Wirhers, R.L. The phase diagram and tetragonal superstructures of the rare earth cobaltate phases $\mathrm{Ln}_{1-x} \mathrm{Sr}_{\mathrm{x}} \mathrm{CoO}_{3-\delta}\left(\mathrm{Ln}=\mathrm{La}^{3+}, \mathrm{Pr}^{3+}, \mathrm{Nd}^{3+}, \mathrm{Sm}^{3+}, \mathrm{Gd}^{3+}, \mathrm{Y}^{3+}, \mathrm{Ho}^{3+}, \mathrm{Dy}^{3+}, \mathrm{Er}^{3+}\right.$, $\mathrm{Tm}^{3+}$ and $\left.\mathrm{Yb}^{3+}\right)$. J. Solid State Chem. 2004, 177, 1886-1895. [CrossRef]

32. Nong, N.V.; Yanagiya, S.; Monica, S.; Pryds, N.; Ohtaki, M. High-Temperature Thermoelectric and Microstructural Characteristics of Cobalt-Based Oxides with Ga Substituted on the Co-Site. J. Electron. Mater. 2011, 40, 716-722. [CrossRef]

33. Shannon, R.D. Revised effective ionic radii and systematic studies of interatomic distances in halides and chalcogenides. Acta Cryst. 1976, A32, 751-767. [CrossRef]

34. Radaelli, P.G.; Cheong, S.-W. Structural phenomena associated with the spin-state transition in $\mathrm{LaCoO}_{3}$. Phys. Rev. B 2018, 66, 094408. [CrossRef]

(C) 2020 by the authors. Licensee MDPI, Basel, Switzerland. This article is an open access article distributed under the terms and conditions of the Creative Commons Attribution (CC BY) license (http://creativecommons.org/licenses/by/4.0/). 